\title{
Optimum Board Size for Indonesian Public Companies
}

\author{
Komang Ayu Krisnadewi ${ }^{{ }^{*}}$, Wayan Pradnyantha Wirasedana ${ }^{1}$ \\ 1) Fakultas Ekonomi dan Bisnis, Universitas Udayana, \\ Kampus Unud Bukit Jimbaran Badung, Bali, Indonesia \\ Corresponding author, Email: *komangayukrisnadewi@unud.ac.id, ochaw@unud.ac.id
}

\begin{abstract}
This research aims to investigate variables affecting board size in public companies listed on the Indonesian Stock Exchange (IDX) and optimum board size which maximizes firm's value measured by Price to Earnings Ratio (PER), Price to Book Value (PBV), and Tobin's Q. Using 4,379 observations from 2007 to 2015 of IDX data, this research finds that liquidity, solvability, activity, and profitability affect board size significantly in quadratic form. In addition, it is suggested that the optimum board size for small companies is four directors while the size for big companies is six to seven directors.
\end{abstract}

Keywords: Board size, firm's value, PER ratio, PBV, Tobin's Q

\section{INTRODUCTION}

To operate a company, investing in the human and economic resource is a must. These resources are managed by the management to achieve their goals, one of which is profit in short term, mid-term, and long term. To achieve that goal, the company creates several interconnected divisions called organizational structure. Organizational structure must be designed in a way to ensure that each division is able to communicate as a part of the coordination process. Wolf (on [33]) stated that organizational structure directly influenced successful organizational strategies.

Decision making is the main process of managing an organization. Individual's decision makings are generally used for non-complex problems. [28] stated that individuals think and act rationally before making any decision, and because of that, individuals tend to select profitable decisions. Generally, larger companies have more complex problems. For a complex organization, group decision making is the norm. The presence of others significantly affects an individual's decision process. However, decision making studies found that group dynamics could obstruct them from achieving good decision making [10]. Because of that, the group should have an optimum number of members, not too few nor too many. The board size optimization needs limitation or constraint.

[28] stated that there are several factors that affected the accomplishment of a group, one of which is team composition. In a team composition, their size decided their accomplishment. [28] stated that the most effective team size is five to nine people because there will be coordination problems and the need to conduct several meetings for making decisions. In-group conflicts are common occurrences, considering differences between individuals such as perception, social background, education, personality, dreams, experience, or any others [30]. However, [30] stated that different opinions or perceptions could be seen as an advantage and not a weakness.

Decision making is affected by organizational structure [33]. Board size plays an important role in managing a corporation because directors are responsible for managing companies' business. Directors are the best people trusted by the owner to manage the company efficiently and effectively. The question is, what is the optimum board size that could produce maximum companies' value? The optimum number refers to a condition where an increase or decrease of directors would not decrease the companies' value.

Studies on the relation between board size and performance or the company's value had been conducted by several researchers, but there is no conclusive result. [25] and [16] found that there is a linear non-monotonous relation between board size and the company's value. [37], [7], [11], [29], and [4] research proved that there is a negative influence between board size and performance. Their research used different proxies to calculate performance/value: Toni's Q [37], profitability [7], return stock [11], net profit [29], and ROA [4].

[1] and [20] found that board size positively influences ROA and Tobin's Q. On the other hand, [1] proved that board size negatively influences ROE and Market to Book. [20] found that board size negatively influences sales growth performance. Considering the diverse research results 
(positive and negative), [20] suggested Ghanaian public company to use a smaller board size to achieve effective performance. The average board size in that research is 8 directors.

[31] research proved a different result from the previous one. They found that board size gives a quadratic effect on the company's value that uses price to earnings ratio (PER), price to book value (PBV), and Tobin's $\mathrm{Q}$ as its proxy. The quadratic effect in this research means that until a certain number of directors is reached, increasing the board size will raise the company's value. On the contrary, if the benefit of increasing the board size is lower than the cost, it will lower the company's value.

[13] found that a larger board size would have larger control of the company, and this would cause them to feel entrenchment, which will affect the company's value. [6] stated that a variation of board size is caused by different characteristics of the companies. However, it is also possible for companies with high homogeneity to have the same board size. [9] stated that a multi-variant approach has a huge chance to find the optimum board size to maximize the company's value.

Based on those different research results, this study aims to find the optimum board size for companies listed on the Indonesian Stock Exchange (IDX) to maximize the company's value. The optimum number in this research is the number that produced the maximum company's value. In accordance to decision making and organization theory, a good decision could be made by a group containing several individuals with different perspectives, which is a strength on one hand and an obstacle on the other hand, as the group's dynamic could prevent a good decision making.

[21] found that big and small companies have a vastly different board structure. Thus, this research differentiates their optimum board size. [37] stated that the company's decrease in value is different for small, medium, and large companies as the result of increasing the same number of directors. The largest impact is felt by small companies because their small job complexity is burdened by the cost inefficiency and decision making because of the increase of board size. [37] used a log of total capital to measure market equity value at the end of the year, added with long term debt and preferred stock estimation to measure the scale of the company.

To achieve an optimum result, a company would surely face their limitations or obstacles. On obstacle theory, it is mentioned that operation results could be improved if the limitations/ obstacles are being handled well [2]. To determine the optimum board size that produced maximum value, companies are faced with liquidity, solvability, activity, and profitability's level. Companies with good liquidity, solvability, activity, and profit are able to have more directors than companies with financial problems. Director's compensation requires no small amount of money. As a result, financially troubled companies could not pay this compensation, and that means an increase of board size is not a good option for them.

\section{Liquidity Ratio}

Liquidity ratio calculates companies' short term liquidity by observing current assets relative to current debts. Bad long term liquidity ratio also affects solvability [12] Companies' inability to fulfill their current obligation is an extreme liquidity problem. This problem can lead to insolvency and bankruptcy. Although accounting uses sustainability concept assumption, there is still a need to analyze liquidity and solvability [32]. Through liquidity ratio, owners could measure managements' capability in managing the funds, which includes paying their short term obligation. With this ratio, management is able to monitor the available treasury to fulfill the obligations in due time [14].

A company's liquidity rate is generally used as a benchmark on decision making of people related to them, one of which is stakeholders. Liquidity is a fund or cash position of a company and their capability in fulfilling their obligation/debt in due time. Liquidity is important to companies because good liquidity enables them to pay various short term obligations, such as paying salaries, debts to suppliers, tax obligation, or any other. Cash bonus for directors could incite a spike of performance. If a company is lacking in liquid assets, they are in danger of fulfilling their short term obligation, which includes paying director's cash bonus. On the contrary, it is a bad sign if a company's liquid assets far exceed their short term obligation (over liquid). Over liquid indicates that the company is not capable of productively managing their assets [36].

H1a: Liquidity ration influence the board size.

\section{Solvability Ratio}

To do their business, companies need adequate funds. Solvability shows a company's capability to fulfill all their short and long term obligetions. Un-solvable companies are companies whose assets are lower than their debts. Thus, directors have to grasp the company's optimum short and long term obligation levels. Companies with debts are not worse than those without. [17] assumed 
debt as an effective control mechanism towards management, even more so if the directors are reluctant to pay cash dividends to the stakeholders even when their companies have a huge free cash flow.

[3] found that debt structure and other financial performance is linear with companies' value. [5] found that debt could become an effective corporate governance mechanism in Thailand and Indonesia to prevent management from doing things that are good for them but bad for others. [15] found that companies' capital structure is determined by their liquidity, solvability, activity, and profitability. Further explanations show that this capital structure affects various strategic decisions, including deciding the board size. [18] found that capital structure's decision making heavily depends on liquidity management on Sri Lanka Telekom PLC. Because of that, companies have to focus on liquidity management in deciding their capital structure so that they could achieve their long term value.

[14] stated that one of the uses of solvability ratio is to measure a company's assets capability in fulfilling every obligation, including the permanent obligation to pay their installment loan. Like with liquidity, companies with good solvability rate are allowed to have a higher number of directors than those who experienced solvability problem. Unsolvable companies surely will not be able to pay the compensations, and thus adding the number of directors is not a good idea.

H1b: Solvability ratio is linear to board size

\section{Activity Ratio}

Companies' activity such as buying and selling inventories influenced their sustainability. Inventory with high turnover rate means their sales happen not long after they were bought. High turnover rate will increase the cash flow quality. Better quality cash flow will increase a company's management and operational capability, enabling them to pay off their debts and all obligations, which include paying a cash dividend to stakeholders. Activity theory is used to measure a company's effectivity in using their assets, as well as measuring a company's efficiency in making use of available resources. This resource is also used to measure a company's capability in doing daily activities.

One way of measuring activity ratio is by observing the total assets' turnover, the comparison between sales and assets. Companies with low assets turnover are having a surplus of assets, which means that those assets have not been fully used on their sales [14]. The produced sales will create cash for companies. Considering that the director's compensation is linked with cash, com- panies with low assets turnover will not be able to pay this compensation, thus increasing the board size will be seemingly impossible.

H1c: Activity ratio is linear with board size

\section{Profitability Ratio}

Profitability is a company's ability to get profits on certain periods. Profitability influences investor's investment policy. Company's capability in producing profits attracted investors to invest their funds to expand their business, on the other hand, low profitability causes investors to withdraw their funds. For the company itself, profitability can be used as a tool to evaluate management effectiveness. Profitability also holds an important role in long term sustainability because profitability indicates the future prospect of the company. Because of that, every firm will always try their hardest to increase their profitability, as the higher their profitability is, the safer their sustainability.

Profitability ratio is also used to measure management effectiveness in operating the company. This ratio shows the capability of a company in creating profits through their ability and resources. The higher the assets' returns, the higher their net profit for every single unit of money invested in those assets [14]. When the profitability is low, it could indicate a not yet optimum performance by the director, thus increasing the board size could be needed to support performance optimization. However, non-profitable companies may not need an increase in board size considering this condition could cause them to be unable to pay extra compensations.

$\mathrm{H}_{1 \mathrm{~d}}$ : Profitability ratio is linear to board size

\section{Companies' Value}

In agency theory, the principal found the company and appointed agents with the hope that the agents will work their hardest to maximize the principal's wealth and welfare. For public companies listed on the capital market, stock market price reflected the company's value. If the market responded positively, the stock price will increase, which also means an increase in the company's value.

[23] researched on factors that influence executive compensation in China and found that there is a positive connection between compensation and performance. Executive compensation surely depends on executive size, the board of directors. Wardhani's research on [35] stated that there is a significant and positive relation between board size in deciding the possibility of the company having financial distress. [35] studied liquidity ratio in predicting companies' financial problem. Liquidity ratio shows the ability of a company in fulfilling their short term financial obligation. The higher 
their capability in that, the smaller the possibility of having financial distress.

A contradictory result is shown by [8] who stated that there is a significant yet negative relation between board size and financial problem, which means the larger the board size is, the smaller the potential of a financial problem arising. Board of Directors will decide on the company's short term and long term policies/strategies. This is in accordance with Pearch and Zahra's research (1992) who stated that board size and diversities give advantages to companies because it will create connections with outsiders to ensure resources availability. Thus, the board is an important mechanism in corporate governance, where its existence decides the company's performance [35]. Proof on board size effectivity is still not clear because there are several different findings. Those different results may be an indication that board size influence on performance depends on each companies' characteristics (Wardhani on [35]).

Board of directors as a part of structural organization carries out operational activities to achieve the expected goals. A more complex structure needed more directors' composition. Directors are issuer's organ or authorized public companies and have full responsibility on Issuer or Public Companies' management for Issuer or Public Companies' interests, corresponded with Issuer or Public Companies' purposes and objectives, as well as represented Issuer or Public Companies, inside or outside the court, in accordance with articles of association [26]. Thus, directors have to fulfill management functions to achieve their company's goals.

Directors on the board of directors communicate with each other in performing coordination for decision making. Effectivity from a large board size may decrease considering the occurrence of miscommunication and decision making. The board size really determined the efficiency and effectivity of decision making in performing the managerial functions. A larger board size contrarily lowered the company's value because they took too much time on making decisions, as too many heads are making the decisions [37].

$\mathrm{H} 2$ : The optimum board size is different between large and small companies.

\section{RESEARCH METHOD}

\section{Research Design}

This research used board size and board of directors as its dependent variables. On independent variables, there are liquidity ratio (ratio between current assets besides stocks and current debts), solvability ratio (ratio between total debts and total assets), activity (ratio between total income and total assets), and profitability (ratio between net profit and average assets). To answer the second problem, this research operates several independent variables. In deciding the optimum board size, this research decided on an aim, that is to maximize the value of companies with liquidity, solvability, activity, and profitability as the problems, as well as the companies' total assets to divide large and small companies based on their assets (a company will be categorized as a large company if it has a larger than average asset). The research design is shown in Picture 1.

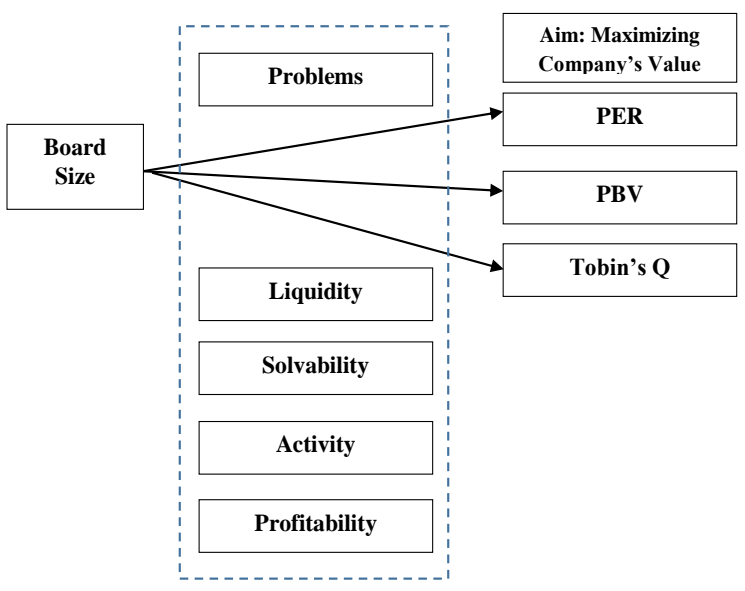

Picture 1. Research Design

Company's value as a goal is measured with three variables:

a) Price to earnings ratio, the ratio between stock market price and company's profit per share

b) Price to book value, the ratio between stock market price and company's book value of equity

c) Tobin's $Q$, the ratio between the market value of equity (after being added with a book value of debt) and book value of total assets

Previous research on company's value usually used Tobin's Q as their proxy. However, seeing that Tobin's Q initial formula is the market value of assets divided by replacement cost of assets, and both variables' data is hard to get, many researchers modified that initial formula. Tobin's Q formula that was modified by [22] changed market value of assets with a market value of equity, added with a book value of debts, while replacement cost is replaced with a book value of total assets because of the difficulty to find the data needed for the initial formula. Even though it is said to be accurate with pre-modified formula, the principle of the modified formula is really identical with multiples principle.

$\mathrm{P} / \mathrm{E}$ divided market value of equity (market price per share) with earnings per share (net profit 
per share), P/B divided market value of equity (market price per share) with book value of equity, P/S divided market value of equity (market price per share) with sales revenue per share, while modified Tobin's Q divided market value of equity (market price per share) after being added with book value of debts with book value of total assets. This caused multiples to be widely used on the intrinsic value of shares' fundamental analysis (which also means the company's value) by academics and practitioner. Brahmana and Hooy (2011) found that between PER (or P/E), PBV (or $\mathrm{P} / \mathrm{B}$ ), and P/S, multiple PER is the best proxy.

This research aims to give empirical evidence on 1) the influence of some financial variables (company's fundamentals: liquidity, solvability, activity, and profitability) to board size, and 2) the optimum board size for large and small company to maximize the company's value (Price to Earnings Ratio or PER, Price to Book Value or PBV, and Tobin's Q). This study is done by using multiple linear regression to answer the first aim, while the second aim is answered by using linear programming approach.

\section{Operational Variables Definition}

a) Price to Earnings Ratio (PER), the ratio between stock market price and company's profit per share

b) Price to Book Value (PBV), the ratio between stock market price and company's book value of equity

c) Tobin's $Q$ (TOBINSQ), the ratio between the market value of equity (after being added with a book value of debt) and book value of total assets

d) Board size (BOARD), the number of people in the company's board of directors

e) Liquidity (LIQUIDITY), the ratio between current total asset aside from stock and current total debt

f) Solvability (SOLVABILITY), the ratio between total funds and the company's total asset

g) Activity (ACTIVITY), the ratio between total income and the company's total asset

h) Profitability (PROFITABLITY), the ratio between net profit and the company's average asset

i) Asset (ASSET), company's total asset

\section{Collecting and Analyzing Data}

This research gathered secondary data through observing financial report prepared by companies and published on the Indonesian Stock Exchange. The population in this research are all issuers registered on Indonesian Stock Exchange from 2007 to 2015, and all population members that are used in this research. Table 2 shows this research's population and samples.

Table 1. Research Samples

\begin{tabular}{lccccccccc}
\hline Notes & 2007 & 2008 & 2009 & 2010 & 2011 & 2012 & 2013 & 2014 & 2015 \\
\hline Population & 412 & 432 & 439 & 501 & 511 & 515 & 519 & 522 & 528 \\
Sample & 412 & 432 & 439 & 501 & 511 & 515 & 519 & 522 & 528 \\
\% Population & 100 & 100 & 100 & 100 & 100 & 100 & 100 & 100 & 100 \\
\hline
\end{tabular}

Teknik analisis data dilakukan dengan dua tahap, sesuai dengan jumlah rumusan masalah. Rumusan masalah pertama dianalisis dengan teknik regresi linear berganda dengan persamaan sebagai berikut.

Data analysis was done in two steps, in accordance with the number of research questions. The first problem was analyzed using multiple linear regression, the equation is as written below:

BOARD $=\beta_{0}+\beta_{1}$ LIQUIDITY $+\beta_{2}$ LIQUIDITY $^{2}+$ $\beta_{3}$ SOLVABLITY $+\beta_{4}$ SOLVABILITY ${ }^{2}$ $+\beta_{5}$ ACTIVITY $+\beta_{6}$ ACTIVITY $^{2}+\beta_{7}$ PROFITABILITY $+\beta_{8}$ PROFITABILI$\mathrm{TY}^{2}+\varepsilon$

The second problem was analyzed using linear programming approach. The researcher used this approach to seek the optimum solution between several available solutions, considering the obstacle and limitation to fulfilling the aims. In this approach, the company's aim is to maximize their value (PER, PBV, and Tobin's Q). Considering the value achievement of the company is by using board size, the limitation is liquidity, solvability, activity, and profitability.

a) MODEL 1

Object: Optimum board size in large companies (BIG - B) and small companies (SMALL - S)

Aim Function: Max (PER)

Problem Function: (LIQUDITY) B + (LIQUIDITY) $\mathrm{S}<$ INDUSTRY AVERAGE LIQUIDITY (SOLVABILITY) B + (SOLVABILITY) $\mathrm{S}<$ INDUSTRY AVERAGE SOLVABILITY (ACTIVITY) $\mathrm{B}+$ (ACTIVITY) $\mathrm{S} \leq$ INDUSTRY AVERAGE ACTIVITY (PROFITABILITY) B + (PROFITABILITY) $\mathrm{S} \leq$ INDUSTRY AVERAGE PROFITABILITY

$\mathrm{B}>0$

$\mathrm{S}>0$

b) MODEL 2

Object: Optimum board size in large companies (BIG - B) and small companies (SMALL - S)

Aim Function: Max (PBV)

Problem Function: (LIQUIDITY) B + (LIQUIDITY) $\mathrm{S} \leq$ INDUSTRY AVERAGE LIQUIDITY (SOLVABILITY) $\mathrm{B}+$ (SOLVABILITY) $\mathrm{S} \leq$ INDUSTRY AVERAGE SOLVABILITY (ACTIVITY) $\mathrm{B}+$ (ACTIVITY) $\mathrm{S} \leq$ INDUSTRY AVERAGE ACTIVITY (PROFITABILITY) B + 
(PROFITABILITY) $\mathrm{S} \leq$ INDUSTRY AVERAGE PROFITABILITY

$\mathrm{B}>0$

$\mathrm{S}>0$

c) MODEL 3

Object: Optimum board size in large companies (BIG - B) and small companies (SMALL - S)

Aim Function: Max (TOBINSQ)

Problem Function: (LIQUIDITY) B + (LIQUIDITY) $\mathrm{S} \leq$ INDUSTRY AVERAGE LIQUIDITY (SOLVABILITY) B + (SOLVABILITY) $\mathrm{S} \leq$ INDUSTRY AVERAGE SOLVABILITY (ACTIVITY) $\mathrm{B}+$ (ACTIVITY) $\mathrm{S} \leq$ INDUSTRY AVERAGE ACTIVITY (PROFITABILITY) B + (PROFITABILITY) $\mathrm{S} \leq$ INDUSTRY AVERAGE PROFITABILITY

$\mathrm{B}>0$

$\mathrm{S}>0$

\section{RESEARCH RESULT AND DISCUSSION}

\section{Descriptive Statistics}

Table 2 shows the descriptive statistics of the variables used in this research. For the first objective of the research, board size (BOARD) is used as dependent variable, while liquidity (LIQ, solvability (SOL), activity (ACT), and profitability (PRF) variables are operated as independent variables. For the second objective, independent variable ASS is used to classified large and small companies. Companies with higher than average total asset are classified as large companies, while those with the lower total asset are classified as small companies. Independent variables PER, PBV, and Tobin's $Q$ are operated as aim function variables in linear programming. Problem function variables for the second objective are liquidity, solvability, activity, and profitability.

Table 2. Descriptive Statistics

\begin{tabular}{|c|c|c|c|c|c|}
\hline $\begin{array}{c}\text { Descriptive } \\
\text { Statistics } \\
\end{array}$ & ASS & LIQ & SOL & ACT & PRF \\
\hline $\begin{array}{c}\text { Total } \\
\text { Observations }\end{array}$ & 4.379 & 4.379 & 4.379 & 4.379 & 4.379 \\
\hline Average & 130.038 & 12,03 & 32,42 & 44,32 & 89,34 \\
\hline $\begin{array}{l}\text { Standard } \\
\text { Deviation }\end{array}$ & 10.851 & 1,08 & 17,23 & 18,32 & 58,43 \\
\hline Median & 78.387 & 12,09 & 29,74 & 33,94 & 12,38 \\
\hline Maximum Value & 368.393 & 14,80 & 107,99 & 53,49 & 133,48 \\
\hline Minimum Value & 44.498 & 7,90 & 4,63 & 4,82 & 32,49 \\
\hline $\begin{array}{c}\text { Descriptive } \\
\text { Statistics }\end{array}$ & PER & PBV & TOBINSQ & BOARD & \\
\hline $\begin{array}{c}\text { Total } \\
\text { Observation }\end{array}$ & 4.379 & 4.379 & 4.379 & 4.379 & \\
\hline Average & 17,80 & 15,39 & 0,77 & 5,50 & \\
\hline $\begin{array}{l}\text { Standard } \\
\text { Deviation }\end{array}$ & 105,73 & 98,78 & 0,14 & 0,49 & \\
\hline Median & 9,1 & 9,92 & 0,58 & 6,00 & \\
\hline Maxim & $2.132,72$ & $1.263,73$ & 1,2 & 9,00 & \\
\hline Minimum Value & $-482,37$ & $-313,21$ & 0,22 & 4,00 & \\
\hline
\end{tabular}

Source: Descriptive Statistics Output using EViews

\section{Test Results}

Table 3 shows the regression test results of liquidity, solvability, activity, and profitability's influence on board size.

Table 3. Liquidity, Solvability, Activity, and Profitability's Influence on Board Size - Regression Test Results Summary

Dependent Variable: Board Size (BOARD)

Method: OLS

Total Observations: 4.379

\begin{tabular}{|c|c|c|c|c|}
\hline Variable & $\begin{array}{c}\text { Coefficien } \\
\text { t }\end{array}$ & $\begin{array}{l}\text { Std. } \\
\text { Error }\end{array}$ & t-Stat & P-Value \\
\hline Constants & 19,5800 & 8,5000 & 2,3035 & 0.0035 \\
\hline LIQ & 0,3483 & 0,9384 & 0,3711 & 0.7450 \\
\hline $\mathrm{LIQ}^{\wedge} 2$ & $-2,0487$ & 1,3947 & $-1,4689$ & 0.0250 \\
\hline SOL & 0,8943 & 0,9487 & 0,9427 & 0.1985 \\
\hline $\mathrm{SOL}^{\wedge} 2$ & $-2,3984$ & 0,5379 & $-4,4588$ & 0.0010 \\
\hline $\mathrm{AKT}$ & 0,5875 & 0,8948 & 0,6566 & 0.1648 \\
\hline $\mathrm{AKT}^{\wedge} 2$ & $-2,2714$ & 0,3945 & $-5,7577$ & 0.0010 \\
\hline PRF & 0,5758 & 0,7947 & 0,7246 & 0.1537 \\
\hline $\mathrm{PRF}^{\wedge} 2$ & $-2,1225$ & 0,5459 & $-3,8881$ & 0.0030 \\
\hline$\overline{\mathrm{R}^{2}}$ & & & & 0,4585 \\
\hline $\operatorname{Adj} R^{2}$ & & & & 0,5545 \\
\hline F-Statistic & & & & 19,726 \\
\hline P-Value F-Statistic & & & & 0,0000 \\
\hline
\end{tabular}

Source: Regression Test Results using EViews

P-value F-statistics in Table 3 shows that all fundamental variables (liquidity, solvability, activity, and profitability) simultaneously affect the board size (BOARD). Thus, hypothesis 1a, 1b, 1c, and $1 \mathrm{~d}$ could be accepted. However, looking closely at each independent variables' $\mathrm{p}$-value t-statistic, the variable that has significant influence (on signification level $5 \%$ and $1 \%$ ) are quadratic variables. This indicates that the influence of liquidity, solvability, activity, and profitability have quadratic influence with negative regression coefficient. This negative sign indicates a parabolic graph that opens downwards with maximum extreme value. In other words, until certain levels, an increase in liquidity, solvability, activity, and profitability can be followed by increasing the board size. However, after passing the optimum level, the board size declines as this company's fundamental indicator increases.

\section{Optimum Board Size for Large and Small Companies Calculation Result}

With the help of Mathematica ${ }^{\mathrm{TM}}$ programming software, the researcher received the result as shown in Table 4 below. The syntax for Linnear Programming using Mathematica ${ }^{\mathrm{TM}}$ is given in Attachment. 
Tabel 4. Optimum Board Size via Linear Programming

\begin{tabular}{cccc}
\hline Company & $\begin{array}{c}\text { Model 1 } \\
\text { (PER) }\end{array}$ & $\begin{array}{c}\text { Model 2 } \\
\text { (PBV) }\end{array}$ & $\begin{array}{c}\text { Model 3 } \\
\text { (TOBIN'S Q) }\end{array}$ \\
\hline Large & 7 & 6 & 7 \\
Small & 4 & 4 & 4 \\
\hline
\end{tabular}

Source: Linear Programming Result using Mathematica $^{\mathrm{TM}}$ Programming Software

Calculation of the optimum board size (that could maximize company's value with PER, PBV, and Tobin'sQ proxies) with several fundamental problems such as liquidity, solvability, activity, and profitability shows 7:4 and 6:4 ratios, each for large and small companies respectively. In other words, to maximize the company's value, the optimum board size for small companies are four people, while the optimum board size for large companies is six to seven people.

\section{Discussion}

Liquidity is a company's capability in to pay or clear their debt or short term obligation [32]. The availability of liquid assets such as cash, credits, and stocks become really important to maintain the company's capability in paying their obligations in due time. Companies should also pay attention to how fast can their liquid asset be converted into cash. If companies have little cash yet there are so many stocks in their warehouse, they in actuality are facing liquidity problem because they need a relatively long time to convert their stock into cash to pay their short term obligations. Companies should also avoid an excessive amount of cash because it does not give profits to them. Good cash management should become an important issue for companies.

When companies experienced liquidity problem, it is a bad idea to increase the board size because it will only increase their financial burden in short term. On the contrary, if their liquidity is rising, increasing board size could very well be done as long as the benefits overweigh the extra costs [24].

Solvability shows companies' capability to pay or clear all their obligations or debts [32]. A solvable company is a company that has enough asset to pay short term and long term obligations. If the company is in a shortage of asset, it will not be able to pay their obligations. On the contrary, if they have too much asset, they will be able to pay their obligations but is not productive.

A solvable company (has the ability to clear all its obligations) is able to increase the board size as long as their value does not reach the optimum point [19]. However, if the company's value (PER, PBV, or Tobin's Q) is already optimum, increasing the board size will only lower their value.
Company's activity such as selling and buying inventory affect their sustainability. Inventory with high turnover rate means their sales happen not long after they were bought. High turnover rate will increase a company's cash flow quality. Better quality cash flow will increase a company's management and operational capability, enabling them to pay off their debts and all obligations, which include paying a cash dividend to stakeholders.

Company with good asset turnover rate is able to have more directors than companies with problems with asset turnover [34] Because compensations for directors require quite an amount of money, companies with low asset turnover will not be able to pay these compensations, thus increasing the board size is not a good idea.

Profitability is a company's ability to get profits on certain periods. Profitability influences investor's investment policy. Company's capability in producing profits attracted investors to invest their funds to expand their business, on the other hand, low profitability causes investors to withdraw their funds. For the company itself, profitability can be used as a tool to evaluate management effectiveness. Profitability also holds an important role in long term sustainability because profitability indicates the future prospect of the company. Because of that, every firm will always try their hardest to increase their profitability, as the higher their profitability is, the safer their sustainability.

Companies with good profitability rate are able to have more directors than those who have problems with profitability [27]. Because compensations for directors require quite an amount of money, non-profitable companies with will not be able to pay these compensations, thus increasing the board size is not a good idea.

Table 4 shows that all liquidity, solvability, activity, and profitability simultaneously affect the board size. Partially, the quadratic form of these variables has more influence on the board size. The result of this research indicates that all those company's fundamental variables quadratically influence the board size. Increasing the variable's ratios tends to increase the board size to an optimum level (which maximized company's value), but after passing the optimum number of directors, it is highly discouraged to increase the board size as it will only lower company's value.

The result of this research shows that the optimum board size is 7:4 and 6:4. These numbers mean that the number of directors on large and small companies are not the same. To maximize PER and Tobin's Q, this research found that the optimum board size is seven for large companies 
and four for small companies. To maximize PBV, the optimum board size is six for large companies and, again, four for small companies. This result is closely similar to [20] research that suggested less than eight directors, which is the average board of directors' numbers in their research.

The board size should be adjusted with the company's financial condition, the complexity of its business, as well as the rivalries. A company's business complexity can be seen from the size of the company, which is the managed total asset in this case. The larger a company, the more complex their problems are, thus there will be a larger board size than smaller companies.

Having a small number of directors is not the best decision too. Decision making by an individual generally means that the problems are not complex. This is in accordance with Pearch and Zahra research on [35], which stated that board size and diversity give an advantage to companies because it will create a network with outsiders to ensure resources availability.

A company's financial condition also affects the board size. This is because directors' compensation is not small. Compensation has an important role in increasing directors' performance. Without proper compensations, their performance will drop, and will even cause a high directors turnover rate in a company. More directors mean more compensation funds are needed.

Even if a company's financial condition allows them to pay the board's compensations, increasing the board size along with the size of the company will not always give the maximum value. This is in accordance with group decision-making theory: a group's dynamic can hinder the efforts to reach a good decision making [10], and the difficulty of having good coordination [28] that may even cause conflicts [30]. This theory is supported by research done by [37], [7], [11], [29], [4], and [20] who have proved the negative influence between board size and company's performance.

\section{CONCLUSION AND SUGGESTION}

\section{Conclusion}

This research aims to investigate variables affecting the board size. This study also calculates the optimum board size which maximizes the firm's value measured by Price to Earnings Ratio (PER), Price to Book Value (PBV), and Tobin's Q. The result shows that liquidity, solvability, activity, and profitability affect the board size significantly in quadratic form. Liquidity, solvability, activity, and profitability variables are simultaneously affecting the board size. Partially, these quadratic form variables significantly affect the board size. To maximize PER and Tobin's Q value, the result of this research suggested seven directors for big companies and four directors for small companies. To maximize PBV, the suggested numbers are six for big companies and four for small companies.

\section{Suggestions}

Increasing liquidity, solvability, activity, and profitability's ratio tends to increase the board size to its maximum level (which maximized company's value), but after reaching the optimum number, increasing the board size would only decrease company's value. The board size should be adjusted to the company's financial condition, their business' complexity, and their industrial rivalries. It is suggested for big companies to have six to seven directors, and four directors for small companies.

Future studies could research the optimum board size for BUMN versus non-BUMN, high versus low capital companies, or various other criteria. The results could then be compared to see their consistency with this research. Future studies could also use other aim function criteria aside from maximizing company's value. For example, maximizing market share, company's reputation, et cetera. Lastly, future studies could add obstacles by combining companies' financial and non-financial variables.

\section{REFERENCES}

[1] Ammari, A., M. Kadria, and A. Ellouse (2014), "Board Structure and Firm Performance: Evidence from French Firms Listed in SBF 120", International Journal of Economics and Financial Issues, 4(3), page $580-590$.

[2] Atkinson, Anthony A., Robert S. Kaplan, Ella Mae Matsumura, S. Mark Young (2012), Management Accounting: Information for Decision Making and Strategy Execution, Sixth Edition, Pearson Education, Inc., Upper Saddle River, New Jersey.

[3] Berger, A.N., and E. Bonaccorsi di Patti (2006), "Capital Structure and Firm Performance: A New Approach to Testing Agency Theory and an Application to the Banking Industry", Journal of Banking \& Finance, 30, page 1065 - 1102.

[4] Bublykova, P (2014), "The Impact of Board Size on Firm Performance: Evidence from Hungary". CEU eTD Collection, page 1- 44 .

[5] Bunkanwanicha, P., J. Gupta, and R. Rokhim (2008), "Debt and Entrenchment: Evidence from Thailand and Indonesia". European Journal of Operational Research, 185, 15781595. 
[6] Coles, J., N. Daniel, and L. Naveen (2007), “Boards: Does One Size Fit All?". Journal of Financial Economics, 20, page 293-315.

[7] Eisenberg, T., S. Sundgreen, and M. T. Wells (1998), "Larger Board Size and Decreasing Firm Value in Small Firms". Journal of Financial Economics, 48, page 35 - 54.

[8] Emrinaldi (2007), "Analisis Pengaruh Praktek Tata Kelola Perusahaan (Corporate Governance) terhadap Kesulitan Keuangan Perusahaan (Financial Distress): Suatu Kajian Empiris", Jurnal Bisnis dan Akuntansi, Vol. 9, No. 1, halaman 88-104.

[9] Gertner, R., and S. Kaplan (1996), "The Value-Maximizing Board”. Unpublished Working Paper, University of Chicago and NBER.

[10] Gitosudarmo, I. dan I Nyoman Sudita (2008), Perilaku Keorganisasian, Edisi Pertama, BPFE Yogyakarta.

[11] Guest, P.M. (June 2009), "The Impact of Board Size on Firm Performance: Evidence from the UK", The European Journal of Finance, 15 (4), page 385-404.

[12] Hanafi, Mamduh M. dan Abdul Halim (2016), Analisis Laporan Keuangan, Edisi 5, UPP STIM YKPN: Yogyakarta.

[13] Harris, M., and A. Raviv (2007), "A Theory of Board Control and Size". Review of Financial Studies, 20, page 293-315.

[14] Hery (2016), Analisis Laporan Keuangan, Integrated and Comprehensive Edition, Edisi 1, Grasindo: Jakarta.

[15] Huang, G., and F.M. Song (2006), "The Determinants of Capital Structure: Evidence from China". China Economic Review, 17, page 1436.

[16] Itto, Y and Shailer, S., 2014, "Asymptotical Relationship between Board Size and Value of Company". Journal of Financial Mathematics. 13, 193-224.

[17] Jensen, Michael (1986), "Agency Costs of Free Cash Flow, Corporate Finance, and Takeovers", American Economic Review, vol. 76, issue 2, pages 323-329.

[18] Kajananthan, R and S. Achchuthan (2013), "Liquidity and Capital Structure: Special reference to Sri Lanka Telecom Plc”, Advances in Management and Applied Economics, 3, page 89-99.

[19] Kelley, A. (2014), "Does Ability to Pay Debts Affect Decision to Change Board Composition?". Journal of Mathematical Finance, 31, page 433-445.

[20] Kyereboah-Coleman, A. and N. Biekpe (2007), "The Relationship between Board Size, Board Composition, CEO Duality, and Firm Perfor- mance: Experience from Ghana”, Corporate Ownership and Control Journal, 4 (2), no page.

[21] Linck, James S., Jeffry M. Netter, and Tina Yang (2008), "The Determinants of Board Structure", Journal of Financial Economics, 87, 2, page 308-328.

[22] Lindenberg, Eric B. and Stephen A Ross (1981), "Tobin's q Ratio and Industrial Organization", The Journal of Business, 54, 1, pages 1-32.

[23] Luo, Yongli (2012), "Executive Compensation, Firm Performance and Liquidity Under Imperfect Corporate Governance", The University of Texas-Pan American, ProQuest Dissertations Publishing

[24] McMurty, M., and T.S. Ralph (2012), "Board Size in Liquid and Illiquid Market", European Journal of Accounting and Finance, 29, page 322-341.

[25] Moody, M.N and Zang, B. (2011), "Board Size and Firm's Value". Journal of International Finance and Economics, 33, 212-222.

[26] Otoritas Jasa Keuangan (2014), "Peraturan Otoritas Jasa Keuangan Nomor 33/POJK.04/ 2014 tentang Direksi dan Dewan Komisaris Emiten atau Perusahaan Publik".

[27] Qian, E., and T. Han (2013), "Profitability and Board Size: Chinese Experience", Chinese Accounting Review. 22, page 343-374.

[28] Robbins, Stephen P., and Timothy A. Judge (2009), Organizational Behavior, $13^{\text {th }}$ Edition. Pearson Education, New Jersey.

[29] Samuel, Eyenubo A. (March 2013), "The Impact of Bigger Board Size on Financial Performance of Firms: The Nigerian Experience", Journal of Research in International Business and Management, 3 (3), page 85-90.

[30] Siagiaan, Sondang P. (2007), Teori Pengembangan Organisasi, Edisi 1, Bumi Aksara, Jakarta.

[31] Sisdyani, Eka A., Komang Ayu Krisnadewi, dan Putu Agus Ardiana (2016), "Pengaruh Nonlinear Pengelolaan Korporasi pada Nilai Perusahaan", Kertas Kerja Penelitian LPPM Universitas Udayana.

[32] Subramanyam, K. R. and John J. Wild (2010), Analisis Laporan Keuangan (Edisi Terjemahan oleh Dewi Yanti), Edisi 10, Buku 2, Salemba Empat: Jakarta.

[33] Tran, Q. and Y. Tian (2013), "Organizational Structure: Influencing Factors and Impact on a Firm", American Journal of Industrial and Business Management, 3, page 229-236.

[34] Trenor, A.L., and C.A. Adams (2014), "Activity Ratios and Their Impact to Board Size", Journal of Contemporary Finance. 43, page 322-341. 
[35] Triwahyuningtias, Meilinda dan Harjum Muharam (2012), "Analisis Pengaruh Struktur Kepemilikan, Ukuran Dewan, Komisaris Independen, Likuiditas dan Leverage terhadap Terjadinya Kondisi Finacial Distress (Studi Pada Perusahaan Manufaktur yang Terdaftar di Bursa Efek Indonesia Tahun 2008-2010)", Diponegoro Journal of Management, 1(1), page 1-14.
[36] Wild, John J, K. R. Subramanyam, Robert F. Halsey (2007). Financial Statement Analysis. Published by McGraw-Hill/Irwin. 9th Edition.

[37] Yermarck, D. (1996), "Higher Market Valuation of Companies with a Small Board of Directors", Journal of Financial Economics, 40, page $185-211$. 